\title{
Correction to: Anthropogenic Tropical Forests
}

\section{Correction to:}

N. Ishikawa, R. Soda (eds.), Anthropogenic Tropical Forests, Advances in Asian Human-Environmental Research, https://doi.org/10.1007/978-981-13-7513-2

Correction to Chapter 01: Commodification of Nature on the Plantation Frontier Noboru Ishikawa and Ryoji Soda

Correction to Chapter 28: Into a New Epoch: Capitalist Nature in the Plantationocene Noboru Ishikawa

The above-mentioned chapters 01 and 28 were originally published as non-Open Access chapters. Later, the sponsoring university have opted for Open Access. The chapters have been reposted as Open Access chapters under the terms of the Creative Commons Attribution-NonCommercial-NoDerivatives 4.0 International License (http://creativecommons.org/licenses/by-nc-nd/4.0/).

The updated versions of the chapters can be found at https://doi.org/10.1007/978-981-13-7513-2_1

https://doi.org/10.1007/978-981-13-7513-2_28

(C) The Author(s) 2021 